\title{
Development of a Performant Method for Glucocapparin Determination in Boscia senegalensis Lam Ex. Poir.: A Study of the Variability
}

\author{
Momar Talla Gueye ${ }^{1,2,3^{*}}$, Dogo Seck ${ }^{4}$, Abdoulaye Diallo ${ }^{1}$, Danny Trisman ${ }^{2}$, Christophe Fischer $^{3}$, \\ Jean-Paul Barthelemy ${ }^{3}$, Jean-Paul Wathelet ${ }^{2}$, Georges Lognay ${ }^{3}$ \\ ${ }^{1}$ Institute of Food Technology (ITA), Hann-Dakar, Senegal \\ ${ }^{2}$ University of Liege, Gembloux Agro-Bio Tech, Unit of General and Organic Chemistry, Gembloux, Belgique \\ ${ }^{3}$ Gembloux Agro-Bio Tech, Unit Analysis, Quality, Risks-Laboratory of Analytical Chemistry, \\ University of Liege, Gembloux, Belgium \\ ${ }^{4}$ Regional Centre for Research in Ecotoxicology and Environmental Safety (CERES/Locustox), Dakar, Senegal \\ Email: "'gueyemt@gmail.com
}

Received December 12, 2012; revised January 12, 2013; accepted January 18, 2013

\begin{abstract}
This study describes a glucocapparin determination method. Based on rapeseed determination of glucosinolate (GSL), the equation of the average straight regression line is $\mathrm{Y}=100.42 \mathrm{X}-0.03\left(\mathrm{R}^{2}=0.9998\right)$. Enzymatic hydrolysis of glucocapparin extracted from leaves and fruits of B. senegalensis, analyzed by SPME-GC-MS confirmed the presence of methylisothiocyanate as the main hydrolysis glucocapparin product. Monitoring glucocapparin contents in B. senegalensis leaves and fruits collected in 4 localities in Senegal showed differences between organs according localities and periods of harvest. Glucocapparin content was very high in dry season particularly in January and the lowest rates were recorded during the rainy period between August and November.
\end{abstract}

Keywords: Boscia Senegalensis; Validation Method; Glucocapparin; Monitoring; Senegal

\section{Introduction}

The glucosinolates (GSLs) are particularly abundant sulphur-containing compounds in the families of the Order Capparales - Brassicaceae, Tovariaceae, Resedaceae, Capparaceae and Moringaceae [1]. At least, 120 GSLs were identified in sixteen angiosperm families including a large number of edible species. The type of major GSL present varies largely between different plant species and the organ considered [2]. GSLs are associated in plants with enzymes called myrosinases (thioglucoside glucohydrolase, EC.3.2.3.1). Their hydrolysis into D-glucose and a variety of breakdown products is responsible for the pungent bitter taste of many cruciferous and spice plants. As a result of mechanical wound or pathogen attack, the GSLs and hydrolyzing enzymes come into contact and produce a number of hydrolytic products, in situ [3]. According to the substrate and the reaction conditions, the secondary products are mainly isothiocyanates, oxazolidines thiones, thiocyanates, nitriles and glucose (Figure 1).

Many properties of GSLs and their hydrolysis products

${ }^{*}$ Corresponding author. are well known. The allylisothiocyanates are used as conservatives in food industry. Although they do not neutralize the free radicals before they can harm cells, as antioxidants and carotenoids would do, GSLs and their hydrolysis products are considered as indirect antioxidants by modulating the activity of xenobiotic metabolizing enzymes [3]. They have a protective effect by inhibiting the proliferation of cancer cells [4]. The hydrolytic products of alkyl and aryl GSL are cytotoxic to Salmonella thyphimurium (Tiedink et al., 1991 cited by [3]. Aurinia sinuate showed a powerful antimicrobial effect on Gram-positive and Gram-negative bacteria and fungi probably by the GSL degradation products such as isothiocyanates and nitriles taking into account their importance in the volatile products [5]. Many other works highlighted the biocide activity of GSL hydrolytic products. Given their occurrence, the use as substitutes to pesticides in seed and stored product treatments is desired in IPM. In this fact, the Capparaceae Boscia senegalensis was successfully tested in cowpea storage and peanut [6-8]. Its efficacy is due to the occurrence of glucocapparin in its organs. Indeed methylisothiocyanate (MITC) is released by hydrolysis of glucocapparin and 

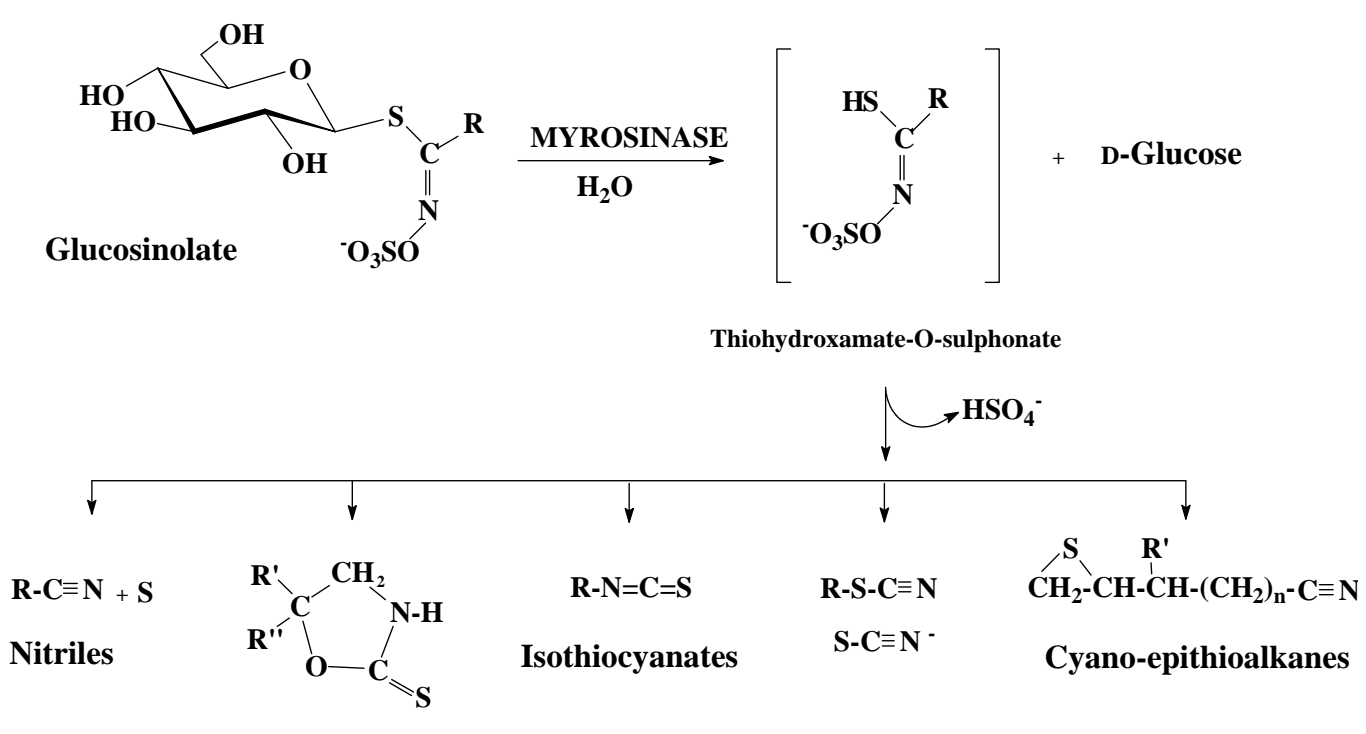

Oxazolidine-2-thiones

Thiocyanates

Figure 1. Myrosinase degradation pattern of glucosinolate.

responsible for the insecticidal activity on the bruchids Callosobruchus maculatus and C. serratus. Glucocapparin was identified in leaves of Cleome spinosa and $C$. chelidonii $[9,10]$. However, glucocapparin is less documented than other glucosinolates, undoubtedly due to the lack of commercial interest in it. It has been reported that in Western Africa, B. senegalensis holds a considerable nutritive value. The fresh and immature seeds are used like lentils after a process of cooking and complex scrubbing. In Senegal, these preparations are sold in the markets. Dried, they are transformed into flour and prepared into a type of couscous which is often used during the hardest scarth. A terrible year of dryness (1958) was baptized "the year of Boscia", because it was with this species and its seeds or "peas" that many people survived [11].

Due to the fact that specific biological effects of different glucosinolates vary considerably, it is appropriate to develop sensitive and reliable method for efficient identification and quantification for the particular glucosinolate under investigation [12].

The object of this work is to develop a reliable and effective method to analyze glucocapparin in leaves and fruits of $B$. senegalensis and to analyze the effect of its localization on main secondary metabolite concentration. Therefore, we adapted the standard ISO 9167-1 method [13] described to analyze the glucosinolates in rapeseeds (Brassica napus). After validation of the analytical method, leaves and fruits of $B$. senegalensis from four localities in Senegal and different seasons are monitored in order to evaluate the variability of glucocapparin. In addition, an identification of the glucocapparin breakdown products is carried out by gas chromatography coupled with the mass spectrometry.

\section{Experimental}

\subsection{Plant Material}

Leaves and fruits of $B$. senegalensis were collected in four localities of Senegal: Dakar (1442'00"N, 1728'00"W), Thies $\left(1656^{\prime} \mathrm{W}, 1448^{\prime} \mathrm{N}\right)$, Louga $\left(1542^{\prime} 00^{\prime \prime} \mathrm{N}, 1612^{\prime} 00^{\prime \prime} \mathrm{W}\right)$ and Richard Toll (1628'00"N, 1541'00"W) between April 2010 and November 2011. Samples were collected from plants with the ripest fruits. Different phenological states leaves were collected at various levels of the plants. The plant identification was done at University of Dakar (IFAN) in the botanical section, maintaining the Integrity of the Specifications.

\subsection{Preparation of Samples}

In the laboratory, samples were dried at ambient temperature $\left(25^{\circ} \mathrm{C} \pm 5^{\circ} \mathrm{C}\right)$ to avoid the premature attack of the myrosinase. For the GSLs extraction, a fine crushing with crusher IKA ${ }^{\circledR} \mathrm{A} 11$ basic was carried out.

\subsection{Determination of Glucocapparin Content}

\subsubsection{Preparation of Sulfatase and of Sinigrine Solution}

Sulfatase: $3 \mathrm{ml}$ of water and $2 \mathrm{ml}$ of ethanol were added to $75 \mathrm{mg}$ sulfatase of Helix Pomatia (Sigma EC3161). The tube was placed in a vortex for 3 min before being centrifuged at $3000 \mathrm{rpm}$ for 10 minutes. The deposit was discarded and $8 \mathrm{ml}$ of ethanol was added to the supernatant. This mixture was agitated again with a vortex machine for 45 minutes after which the supernatant was collected. A last round of centrifugation at $3000 \mathrm{rpm}$ was done after which the residue was transferred in $5 \mathrm{ml}$ of distilled water. 
Sinigrine: Sinigrine was taken as internal standard. A solution $(20 \mu \mathrm{mol} / \mathrm{ml})$ was prepared from the pure product of Sigma Aldrich (Ref.: 51647) which was dissolved in methanol/water $70: 30 \mathrm{v} / \mathrm{v}$ solution.

\subsubsection{Glucocapparin Extraction}

$50 \mathrm{mg}$ of powdered $B$. senegalensis dry leaves or fruits were placed in $12 \mathrm{ml}$ glass tubes. In a water-bath at $74^{\circ} \mathrm{C}$ $\pm 1^{\circ} \mathrm{C}$, it was added in the test tubes $(10 \mathrm{ml}) 4.5 \mathrm{ml}$ of a mixture methanol/water (70/30) beforehand heated to boiling then $1 \mathrm{ml}$ of sinigrine $20 \mu \mathrm{M}$. $4.5 \mathrm{ml}$ of the hot solvent mixture were added again in the glass. The solution is agitated during $15 \mathrm{~min}$ by means of a magnet. The whole was then centrifuged at $3500 \mathrm{rpm}$ during $10 \mathrm{~min}$. The supernatant was recovered thereafter.

\subsubsection{Desulfatation and Purification of Extracted Glucocapparin}

$30 \pm 5 \mathrm{mg}$ of DEAE Séphadex A-25 are placed in a minicolonne ( $1 \mathrm{ml}$ syringe). The column is washed with distilled water ( 2 fold $1 \mathrm{ml}$ ). $\mathrm{pH}$ is adjusted by elution of

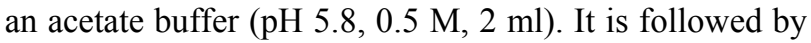
a washing to distilled water $(3 \mathrm{ml}) .1 \mathrm{ml}$ of $B$. senegalensis rough extract was introduced to the column. $1 \mathrm{ml}(2$ fold) of acetate buffer ( $\mathrm{pH} 5.8,0.0025 \mathrm{M})$ are eluded then $150 \mu \mathrm{l}$ of sulfatase were added to column in order to form the desulfocapparin. After 15 hours, desulfocapparin are eluted by $4 \times 0.5 \mathrm{ml}$ of distilled water.

\subsubsection{Measurement of Desulfoglucocapparin by HPLC}

Desulfoglucocapparin are separated and quantified by HPLC (Agilent 1100 coupled to a DAD detector). The column was a VARIAN (INERTSIL 3 ODS-3, length: $100 \mathrm{~mm}$, diameter: $3 \mathrm{~mm}$, diameter of the particles: 3 $\mu \mathrm{m})$. Eluant is composed of a mixture of acetonitrile and water ( $0 \mathrm{~min}$ : water $98.1 \%, 3$ to $33 \mathrm{~min}$ : gradient from $98.1 \%$ to $80 \%$ of water, 33 to 45 min: gradient from $80 \%$ to water $98.1 \%$ ). The mobile phase flow was of 0.5 $\mathrm{ml} / \mathrm{min}$ and $20 \mu \mathrm{l}$ of solutions were injected. The detector was performed at $229 \mathrm{~nm}$ and the temperature of the column was maintained at $30^{\circ} \mathrm{C}$.

By convention, and in respect to the standard ISO [13], glucocapparin is quantified in sinigrine equivalent according to the ratio areas of chromatographic peaks.

\subsubsection{Identification of Glucocapparin Breakdown Products by GC-MS}

Glucocapparin breakdown products and others GSLs were identified by gas chromatography (Agilent HP-6890 CG) coupled to a mass spectrometer (Agilent $5973 \mathrm{~N}$ ). The spectral library was Wiley 275 L. $50 \mathrm{mg}$ of crushed fruits/ leaves were introduced into a $10 \mathrm{ml}$ vial with a septum. $250 \mu \mathrm{l}$ of water and $5 \mathrm{mg}$ of myrosinase (Thioglucosi- dase from Sinapis alba, Sigma) were added to facilitate hydrolysis. The flask was placed at $25^{\circ} \mathrm{C}$ during two hours. The flask was placed at $25^{\circ} \mathrm{C}$ during two hours. The volatile derivatives were sampled by SPME (Carboxen PDMS $75 \mu \mathrm{m}$ fiber Ref 57344Supelco). GC-MS was realized on a HP-5MS ((5\%-phenylmethyl)-siloxane, Agilent) column (length $30 \mathrm{~m}$; diameter $250 \mu \mathrm{m}$; df = $0.25 \mu \mathrm{m}$. The oven temperature program was initiated at $40^{\circ} \mathrm{C}$, held for $5 \mathrm{~min}$ then raised first at $5^{\circ} \mathrm{C} / \mathrm{min}$ to $230^{\circ} \mathrm{C}$, raised in a second ramp at $30^{\circ} \mathrm{C} / \mathrm{min}$ to $280^{\circ} \mathrm{C}$ with a final hold at this temperature for $5 \mathrm{~min}$. The carrier gas is helium (pressure: $49.9 \mathrm{KPa}$, flow: $1 \mathrm{~mL} / \mathrm{min}$ ) and the injector split/splitless (in splitless mode) is maintained at $250^{\circ} \mathrm{C}$. The source of the mass spectrometer was fixed at a temperature of $230^{\circ} \mathrm{C}$ and the scanned mass range was 50 to 350 .

\subsection{Validation of the Glucocapparin Quantification Method}

The procedure of validation is in conformity with the Quality System of Good Laboratory Practice (Monographs of OECD). Glucocapparin not being currently available in the trade, $30 \mathrm{~g} \mathrm{~B}$. senegalensis leaves collected in April 2011 at Richard Toll are crushed (crushing IKA) and introduced into $100 \mathrm{ml}$ methanol. After filtration, the supernatant were extracted with hexane before being evaporated at rotavapor. The liquid residue is then freeze-dried during 48 hours to remove any methanol and water trace. The powder thus obtained is redissolved in $100 \mathrm{ml}$ methanol. Glucocapparin was thereafter defeated and purified on a Sephadex column (cf. 2.3.3) and constituted the desulfoglucocapparin basis solution. For $30 \mathrm{~g}$ B. senegalensis leaves, it was obtained $1.8 \mathrm{~g}$ of defeated powder. Desulfoglucocapparin content of this powder measured by HPLC (cf. 2.3.4.) was 198.23 $\mu \mathrm{mol} / \mathrm{g}$.

The required solutions to the linearity study are prepared by taking aliquots of the basis defeated solution added to a constant volume of $1 \mathrm{ml}$ of defeated sinigrine solution prepared in parallel and according to the same method.

The linearity was established by a variance statistical test based on the 3 lines of calibration resulting from the same solution. The linearity is accepted if the value criticizes $\mathrm{F}$ corresponding to a degree of confidence of 0.95 with 4 and 12 degrees of freedom is lower than value 3.26 (Table of distribution F of Snedecor). If the value of $\mathrm{F}$ is higher than 3.26 , the linearity can be accepted if the two following criteria are observed:

- Determination coefficient $\mathrm{R}^{2}$ is higher than 0.996;

- The accuracy of one 4 th series of calibration solutions shows an error lower or equal to $10 \%$ compared to the calculated straight regression line (excluded with the LOQ $\leq 15 \%$ ). 
The limits of quantification (LOQ) and detection (LOD) were evaluated by the measurement of the background noise of three analyses of the blanco.

$\mathrm{LOQ}=5 \times($ background noise $)+$ Standard deviation.

$\mathrm{LOD}=3 \times($ background noise $)+$ Standard deviation

\subsection{Analyze Statistical for the Follow-Up of the Contents of Glucocapparin}

ANOVA (general linear Model) was applied to the data which were compared thereafter by the test of Tukey with $P<0.05$ on Minitab 16.0.

\section{Results and Discussion}

\subsection{Validation}

Figure 2 represents the study of linearity obtained after glucocapparin desulfatation and five dilutions from a standard solution at $2.6 \mu \mathrm{mol} / \mathrm{l}$. Linearity was determined using an analysis of variance based on tree replicates of each concentration. The non-linearity factor was compared with Snedecor distributions table $(P=0.95)$ with $\mathrm{k} 1=4(6-2), \mathrm{k} 2=12(18-6)$. In these conditions, nonlinearity value was 3.26. The study of the linearity gave a factor $\mathrm{F}$ of 19.72. Equation of the average straight regression line was $\mathrm{Y}=100.42 \mathrm{X}-0.03\left(\mathrm{R}^{2}=0.9998\right)$. The criterion $\mathrm{F}$ of Snedecor was not observed due to an exceptional repeatability between measurements. Linearity can however be accepted. Indeed, accuracy calculated through a 4th series of injections $\left(\mathrm{Y}^{\prime}=98.96 \mathrm{X}+0.55 ; \mathrm{R}^{2}\right.$ $=0.9993$ ) was $99.9 \% \pm 4.5 \%$. This result fulfilled the requirements of our GLP validation procedures. LOQ and LOD estimated were respectively 0.72 and 0.44 $\mu \mathrm{mol} / \mathrm{g}$. These results confirmed the adaptation of the method to measure glucocapparin accurately. LOD and LOQ measured were in agreement with those reported in other studies $[12,14,15]$.

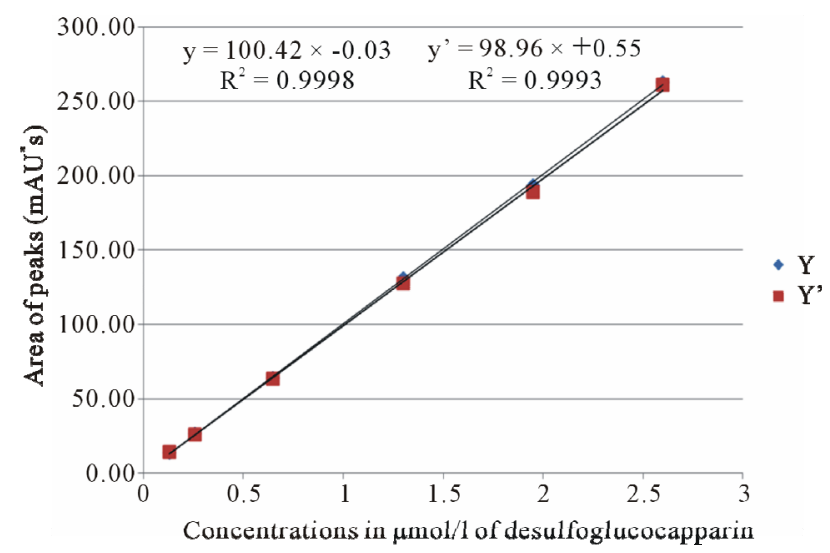

Figure 2. HPLC analysis of desulfoglucocapparin-Determination of linearity. Calibration curves (Y); accuracy calculated through 4th series of analysis ( $\left.Y^{\prime}\right)$.

\subsection{Identification of GSLs and Their Breakdown Products}

The desulfated glucocapparin was identified by HPLC according to its retention time (3.16 min) (injection of a purified solution) and UV spectrum. Identification was performed by analysis of main glucocapparin breakdown product standard (MITC) from Acros 15,751,000 and finally by comparison with Seck et al. (1996) results [6]. No other desulfoglucosinolate appeared on HPLC chromatograms.

After enzymatic hydrolysis (myrosinase) of B. senegalensis leaves and fruits, SPME-GC-MS analysis of the volatiles obtained confirmed the occurrence of methylisothiocyanate, the main hydrolysis glucocapparin product, with retention time at $4.32 \mathrm{~min} ; \mathrm{m} / \mathrm{z}$ (molecular ion and base peak $)=73$; other mass fragments $\mathrm{m} / \mathrm{z}=58(5.8 \%)$ and $\mathrm{m} / \mathrm{z}=45(20 \%)$. Three other minor ITC derived from glucosinolates in traces and not detected by HPLC were also identified. They correspond to: Ethylisothiocyanate, isopropylisothiocyanate and 2-butylisothiocyanate whose probable origins were respectively glucolepidiine, glucoputranjivine and glucocochlearine. However, acetonetrile, another glucocapparin breakdown product has not been identified. Besides ITCs, trans-2-hexenal (green leave volatile compound from lipids metabolism) has also been systematically detected with retention time at $5.06 \mathrm{~min}(\mathrm{~m} / \mathrm{z}=98$, molecular ion). The MS data of all volatile compounds were compared with those from the Wiley $275 \mathrm{~L}$ library to corroborate the identifications.

\subsection{Monitoring Glucocapparin Contents in B. Senegalensis Leaves and Fruits Collected in 4 Localities}

Based on ANOVA results, it was found out that glucocapparin content of organs was significantly different between locations $(\mathrm{F}$ (leaves) $=13.08 ; \mathrm{ddl}=3 ; P<$ $0.001)$; $(\mathrm{F}$ (fruits) $=11.54 ; \mathrm{ddl}=3 ; P<0.001)$ and sampling dates $(\mathrm{F}$ (leaves) $=26.34 ; \mathrm{F}$ (fruits) $=10.40-\mathrm{ddl}=$ 8; $P<0.001)$. Samplings in January and April gave higher glucocapparin contents compared to samplings in August, September and November (except at Richard Toll) which displayed lower values. With regards to variation in glucocapparin content between locations, samples from Richard Toll had the highest contents as compared to Thies and Dakar. This shows an apparently very marked "soil effect". Ecological adaptability of this plant to many environments may explain the observed variability. Indeed, a strong intra-individual variability was noted with this plant. Its morpho-physiological characteristics varied between different locations. Anatomical cuts showed that $B$. senegalensis presented morphological adaptations in the stems, leaves and roots that conferred it a broad ecological adaptability to survive in 
both wet and dry environments [16]. Many studies have shown the variability in GSL contents according to seasons or localities. In Senegal, an earlier study carried out in the same localities revealed an increase in glucocapparin content with increasing latitude [17]. This is in agreement with our results which showed that glucocapparin contents increased from Dakar to Thies and then Louga and were highest in Richard Toll. With Brassica oleracea leaves, total glucosinolate concentration was higher in spring $\left(22.1 \mu \mathrm{mol} \cdot \mathrm{g}^{-1} \cdot \mathrm{dw}\right)$ as compared to that obtained in fall season $\left(13.1 \mu \mathrm{mol} \cdot \mathrm{g}^{-1} \cdot \mathrm{dw}\right)$ [18]. It was also reported that the glucosinolate content increased by 8 -fold in leaves of B. oleracea compared to three other host plants [19]. Other environmental factors such as space, humidity and nutrient availability influenced also the GSL concentration. The type and the quantity of GSLs varied also within tissues of the same plant [1]. As regards the influence of age on $B$. senegalensis glucocapparin concentration, a preliminary study that we carried out in April 2010 in the four localities concerned showed variability in contents from 2 to $440 \mu \mathrm{mol} / \mathrm{g}$ of glucocapparin (locality was not taken into account). The old leaves that became very hard and sometimes pale contained lesser quantities of GSLs. Higher values were directly correlated with the presence of young and mature leaves. Except for rainfall, abiotic factors such as temperature and illumination conditions of the different sites could play a role in glucosinolate content. Indeed, Senegal is a very sunshine country and temperature increase according latitude related to glucosinolate content.

In the four localities, leaves collected in January consistently showed the highest glucocapparin contents (Figures 3-6). At Richard Toll, higher glucocapparin contents were detected in leaves compared to fruits, especially from November to July. However, from June to July, there was no significant difference in glucocapparin content between leaves and fruits (Figure 3). At Thies, the fruits had higher glucocapparin contents than leaves (Figure 4). Glucocapparin content in leaves and fruits collected from Louga and Richard Toll were not signifycantly different between organs (Figure 5). In Dakar, even highest glucocapparin concentrations were obtained in January, the content in Tleaves was lower compared to other localities (Figure 6). With regards to GSLs, even though their content in B. senegalensis was low, the contents detected in our study were generally higher than those reported in other studies. Brassica napus ssp. Pabularia leaves contained GSL concentrations between 1.06 to 49.17 with an average of $19.85 \mu \mathrm{mol} / \mathrm{g}$ [20]; And those from Brassica rapa L leaves displayed different values in two different locations (11.8 to $74.0 \mu \mathrm{mol} / \mathrm{g}$ against 7.5 - $56.9 \mu \mathrm{mol} / \mathrm{g}$ ) [21]. In Barbarea vulgaris ssp. Arcuata the total content of GSL varied between 3 and $46 \mu \mathrm{mol} / \mathrm{g}$ dry wt but generally between 3 and $15 \mu \mathrm{mol} / \mathrm{g}$

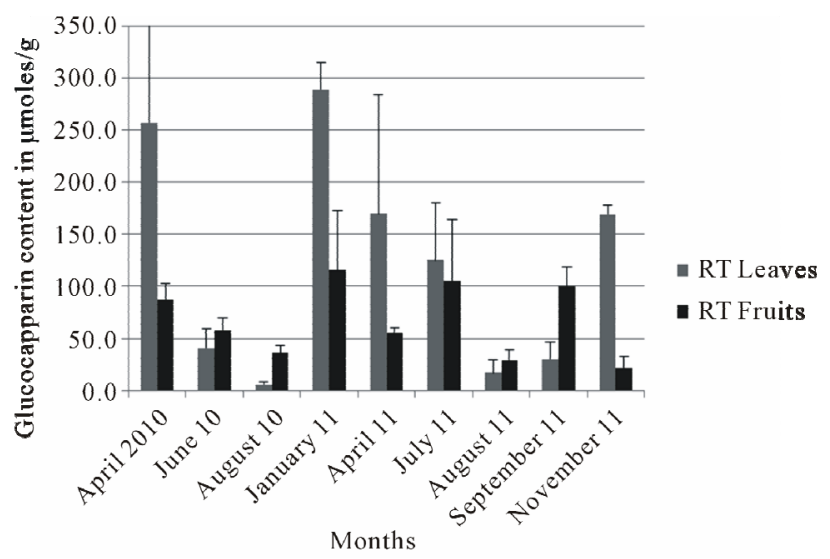

Figure 3. Glucocapparin content of Boscia senegalensis collected at Richard Toll (RT) between 2010-2011.

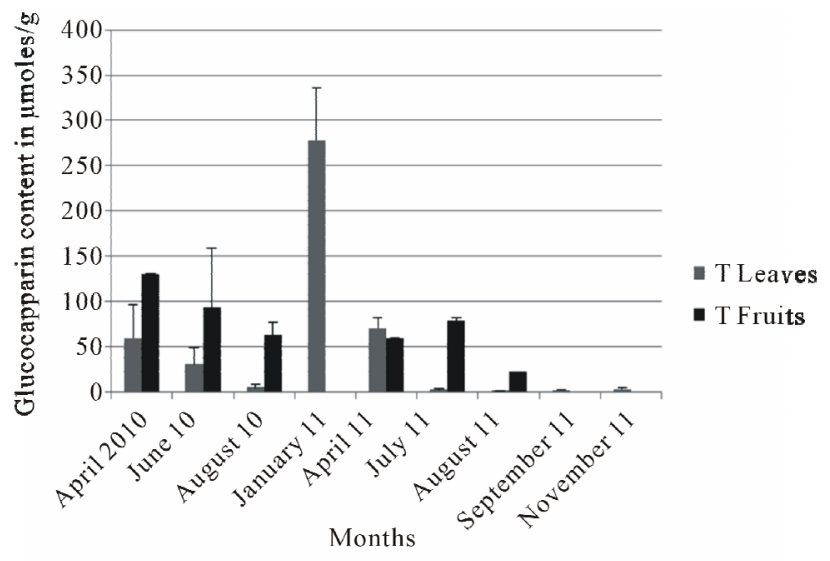

Figure 4. Glucocapparin content of Boscia senegalensis collected at Thies $(\mathrm{T})$ between 2010-2011.

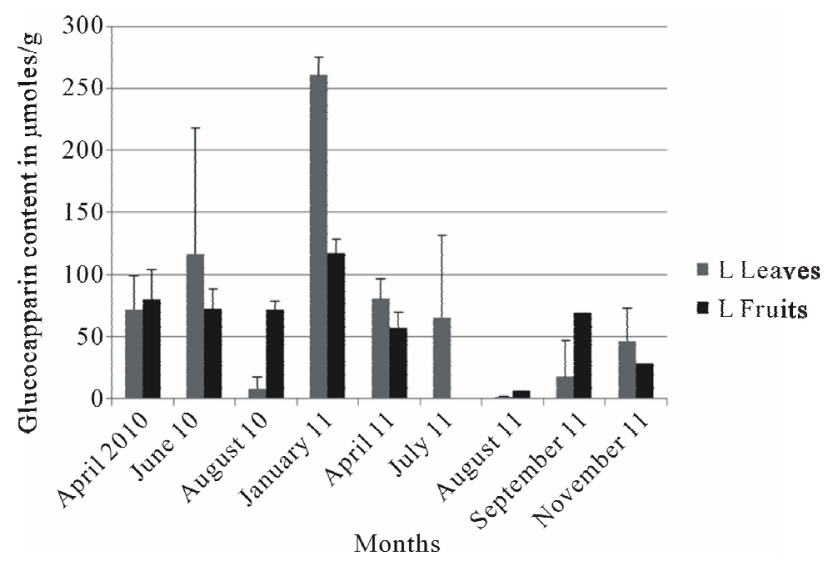

Figure 5. Glucocapparin content of Boscia senegalensis collected at Louga $(\mathrm{L})$ between 2010-2011.

dry wt although it was noted an increase during autumn where it reached $35-75 \mu \mathrm{mol} / \mathrm{g}$ dry wt [22].

In all locations, August, September and to a lesser extent November were the periods with the lowest recorded values. At Richard Toll, between January and August, 


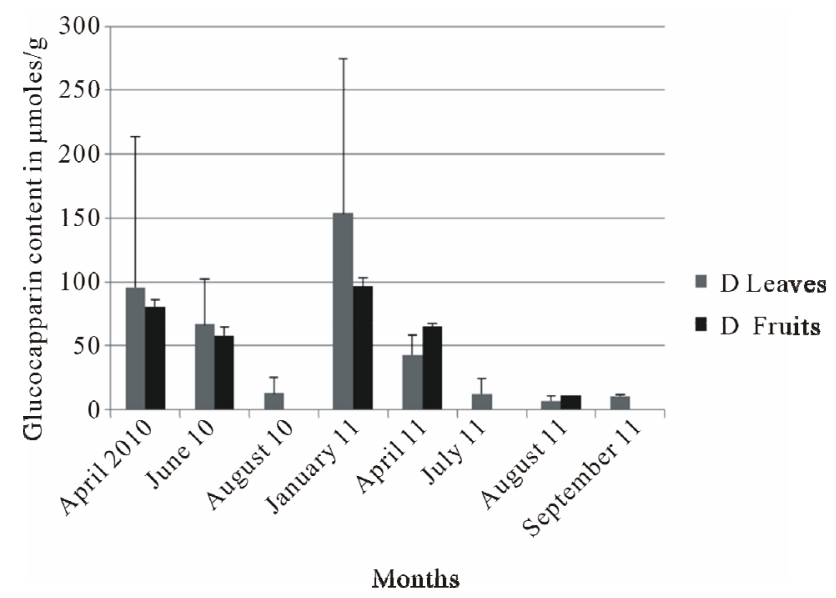

Figure 6. Glucocapparin content of Boscia senegalensis collected at Dakar (D) between 2010-2011.

glucocapparin content decreased by more than six times (Figure 3). In some cases, the scarcity of the fruits between August and November did not make it possible to calculate standard deviations because of single sample size. However, where comparison of the glucocapparin contents between organs was feasible, values of fruits were always higher than those in leaves. This may be related to their ripening process which occurs gradually during the year. On this issue, Richard Toll still constituted an exception since fruits are present all year long contrary to Thies and Dakar.

The period between August and November corresponds to the rainy season in Senegal. We hypothesized that rain was the main factor responsible for the low contents of glucocapparin particularly in leaves. It's likely that the plant confined most of its resources during this period to its vegetative development thus producing only limited quantities of compounds such as glucocapparin for its defence. Such protective substances would be produced under strong moisture stress at the beginning of the dry season (October to November). It is necessary to conduct further studies on B. senegalensis during this period which coincides with the start of harvesting certain crops such as groundnuts. Indeed, a study had revealed that CL50 obtained from this plant compared with those of the pure molecules indicated that leaves and fruits of $B$. senegalensis contained sufficient glucocapparin to release MITC on levels comparable with CL50 of the pure molecule [23]. Higher levels of glucocapparin were observed in January where peaks were obtained in all localities. Such an effect was also reported in the case of radish germs treated with a high concentration of $\mathrm{NaCl}$ solution $(100 \mathrm{mM})$ increasing the production of GSL without inhibiting growth. Alkaline stress would induce genes relevant to GSL synthesis; also,salt could play a role in osmotic adjustment in the case of low water potential [24].

\section{Conclusion}

To the best of our knowledge, this is the first study investigating glucocapparin production by $B$. senegalensis throughout the whole year. After glucocapparin was determined following adaptation for the method of GSLs determination in rapeseed results showed very significant differences in concentrations according to localities and periods of harvest. The rainy season corresponded to the lower productions of glucocapparin. B. senegalensis, known for its insecticidal properties towards pests could be a good candidate to be used for the preservation of food products by taking into account the available quantities of active ingredient (glucocapparin) contained in the different organs. Particular attention should be brought to MITC, its main enzymatic breakdown product that should not be present even in small residues after treatment. In addition, its capacity to reduce the germinative capacity should be investigated before any systematic use in food stocks or seeds.

\section{Acknowledgements}

The "West African Agriculture Productivity Program (WAAPP)" funded by the World Bank and CORAF/ WECARD financed by DFID who sponsored the study are gratefully acknowledged. We thank Baboucarr MANNEH (AFRICA RICE) and Djibril TRAORE (ITA) for their contribution.

\section{REFERENCES}

[1] J. Brown and J. M. Morra, "Subcontract Report NREL/ SR-510-35254, 2000-2002," University of Idaho, Moscow, 2005.

[2] J. W. Fahay, A. T. Zalcmann and P. Talalay, "The Chemical Diversity and Distribution of Glucosinolates and Isothiocyanates among Plants," Phytochemistry, Vol. 56, No. 1, 2001, pp. 5-51. doi:10.1016/S0031-9422(00)00316-2

[3] A. P. Vig, G. Rampal, T. S. Thind and S. Arora, "BioProtective Effects of Glucosinolates-A Review," Food Science and Technology, Vol. 42, No. 10, 2009, pp. 1561-1572.

[4] G. Pappa, M. Lichtenberg, R. Iori, J. Barillari, H. Bartsch and C. Gerhäuser, "Comparison of Growth Inhibition Profiles and Mechanisms of Apoptosis Induction in $\mathrm{Hu}-$ man Colon Cancer Cell Lines by Isothiocyanates and Indoles from Brassicaceae," Mutation Research, Vol. 599, No. 1-2, 2006, pp. 76-87. doi:10.1016/j.mrfmmm.2006.01.007

[5] I. Blažević, A. Radonić, J. Mastelić, M. Zekić, M. Skočibušić and A. Maravić, "Glucosinolates, Glycosidically Bound Volatiles and Antimicrobial Activity of Aurinia sinuata (Brassicaceae)," Food Chemistry, Vol. 121, No. 4, 2010, pp. 1020-1028. doi:10.1016/j.foodchem.2010.01.041 
[6] D. Seck, G. Lognay, E. Haubruge, J.-P. Wathelet, M. Marlier, C. Gaspar and M. Severin, "Biological activity of the shrub Boscia senegalensis (Pers.) Lam ex Poir. (Capparaceae) on stored grain insects," Journal of Chemical Ecology, Vol. 19, No. 2, 1993, pp. 377-389. doi:10.1007/BF00993703

[7] D. Seck, G. Lognay, E. Haubruge, M. Marlier and C. Gaspar, "Alternative Protection of Cowpea Seeds against Callosobruchus maculatus (F.) (Coleoptera: Bruchidae) Using Hermetic Storage or in Combination with Boscia senegalensis (Pers.) Lam ex Poir. (Capparaceae) on Stored Grain Insects," Journal of Stored Products Research, Vol. 32, No. 1, 1996, pp. 39-44. doi:10.1016/0022-474X(95)00035-6

[8] M. T. Guèye, D. Seck, S. Bâ, K. Hell, M. Sembène, J.-P. Wathelet and G. Lognay, "Insecticidal Activity of Boscia senegalensis (Pers.) Lam ex Poir. on Caryedon serratus (O1.) Pest of Stored Groundnuts," African Journal of Agricultural Research, Vol. 6, No. 3, 2011, pp. 6348-6353.

[9] D. W. Griffiths, N. Deightona, A. Birch, E. Nicholas, B. Patrian, R. Baur and E. Städler, "Identification of Glucosinolates on the Leaf Surface of Plants from the Cruciferae and Other Closely Related Species," Phytochemistry, Vol. 57, No. 5, 2001, pp. 693-700. doi:10.1016/S0031-9422(01)00138-8

[10] T. Songsak and G. B. Lockwood, "Glucosinolates of Seven Medicinal Plants from Thailand," Fitoterapia, Vol. 73, No. 3, 2002, pp. 209-216. doi:10.1016/S0367-326X(02)00061-8

[11] M. Baumer, "Arbres, Arbustres et Arbrisseaux Nourrissiers en Afrique Occidentale," Enda-Editions, Séries Etudes et Recherches, Dakar, 1995.

[12] T. Mohn, B. Cutting, E. Beat and M. Hamburger, "Extraction and Analysis of Intact Glucosinolates-A Validated Pressurized Liquid Extraction/Liquid Chromatography-Mass Spectrometry Protocol for Isatis tinctoria, and Qualitative Analysis of Other Cruciferous Plants," Journal of Chromatography A, Vol. 1166, No. 1-2, 2007, pp. 142-151. doi:10.1016/j.chroma.2007.08.028

[13] International Organization for Standardization (ISO), "Determination of Glucosinolate Content-Part 1: Method Using Gradient Elution High-Performance Liquid Chromatography," ISO Standard 9167-1, 2001.

[14] E. Sosinska and M. W. Obiedzinski, "Effect of Processing on the Content of Glucobrassicin and Its Degradation Products in Broccoli and Cauliflower," Food Control, Vol. 22, No. 8, 2011, pp. 1348-1356. doi:10.1016/j.foodcont.2011.02.011

[15] L. Paugam, R. Ménard, J.-P. Larue and D. Thouvenot,
"Optimization of Glucosinolate Separation by Micellar Electrokinetic Capillary Chromatography Using a Doehlert's Experimental Design," Journal of Chromatography A, Vol. 864, No. 1, 1999, pp. 155-162. doi:10.1016/S0021-9673(99)00924-3

[16] A. M. S. Mahamane, "Anatomical Structures of Boscia senegalensis (Pers.) Lam. ex Poir, and Adaptation to Dryness," Sécheresse, Vol. 20, No. 2, 2009, pp. 237-239.

[17] D. Seck, "Développement de Méthodes Alternatives de Contrôle des Principaux Insectes Ravageurs des Denrées Emmagasinées au Sénégal par L'utilisation de Plantes Indigènes," Ph.D. Thesis, Faculté des Sciences Agronomiques de Gembloux, 1994.

[18] M. E. Cartea, P. Velasco, S. Obregón, G. Padilla and A. De Haro, "Seasonal Variation in Glucosinolate Content in Brassica oleracea Crops Grown in Northwestern Spain," Phytochemistry, Vol. 69, No. 2, 2008, pp. 403-410. doi:10.1016/j.phytochem.2007.08.014

[19] S.-Y. Hwang, C.-H. Liu and T.-C. Shen, "Effects of Plant Nutrient Availability and Host Plant Species on the Performance of Two Pieris Butterflies (Lepidoptera: Pieridae)," Biochemical Systematics and Ecology, Vol. 36, No. 7, 2008, pp. 505-513. doi:10.1016/j.bse.2008.03.001

[20] R. Font, M. Del Río-Celestino, E. Cartea and A. De HaroBailo, "Quantification of Glucosinolates in Leaves of Leaf Rape (Brassica napus ssp. pabularia) by Near-Infrared Spectroscopy," Phytochemistry, Vol. 66, No. 2, 2005, pp. 175-185. doi:10.1016/i.phytochem.2004.11.011

[21] G. Padilla, M. E. Cartea, P. Velasco, A. de Haro and A. Ordás, "Variation of Glucosinolates in Vegetable Crops of Brassica rapa," Phytochemistry, Vol. 68, No. 4, 2007, pp. 536-545. doi:10.1016/j.phytochem.2006.11.017

[22] N. Agerbirk, C. E. Olsen and J. K. Nielsen, "Seasonal Variation in Leaf Glucosinolates and Insect Resistance in Two Types of Barbarea vulgaris ssp. arcuata," Phytochemistry, Vol. 58, No. 1, 2001, pp. 91-100. doi:10.1016/S0031-9422(01)00151-0

[23] G. Lognay, M. Marlier, D. Seck, E. Haubruge, J.-P. Wathelet, A. D. Coulibaly, C. Gaspar and M. Severin, "Détection des Molécules Responsables de L'activité Biocide des Feuilles de Boscia senegalensis (Pers.) Lam ex Poir. par Échantillonnage D'espace de Tête et Spectophotométrie de Masse Couplée à la Chromatographie," No. 1, 1994, pp. 117-124.

[24] G. Yuan, X. Wang, R. Guo and Q. Wang, "Effect of Salt Stress on Phenolic Compounds, Glucosinolates, Myrosinase and Antioxidant Activity in Radish Sprouts," Food Chemistry, Vol. 121, No. 4, 2010, pp. 1014-1019. doi:10.1016/j.foodchem.2010.01.040 